\title{
Research on the Practical Teaching System of Business English Based on "Experimental Learning"
}

\author{
Hou, Yanfang \\ School of Foreign Studies, Yangtze University, Hubei, P. R. China \\ houyanfang@yangtzeu.edu.cn
}

Received: 20 Oct 2021; Received in revised form: 20 Nov 2021; Accepted: 01 Dec 2021

(C)2021 The Author(s). Published by TheShillonga. This is an open access article under the CC BY license

(https://creativecommons.org/licenses/by/4.0/)

\begin{abstract}
Practical teaching, as an indispensable part of college teaching system, is an important way to cultivate innovative and entrepreneurial talents. There is still certain gap between the quality of talent training in colleges and the talent demand of social and economic development. This research discusses the reform and practice of practical teaching system with a case study, aiming to explore a new path of the practical teaching system of Business English.
\end{abstract}

Keywords_-Practical teaching system, Business English, Experimental Learning.

\section{INTRODUCTION}

Practical teaching, as an indispensable part of college teaching system, is an important way to cultivate innovative and entrepreneurial talents. In recent years, it has attracted more and more attention of educational researchers and teachers but there is still certain gap between the quality of talent training in colleges and the talent demand of social and economic development. The implementation process and effectiveness of the practical education are far from the expectations. In particular, college students majoring in humanities are emphasized to theoretical learning without sufficient practice, resulting in the lack of practical experience in work. There is a lack of systematical research on practical teaching planning, management and evaluation mechanism.

Business English has become a major in the undergraduate enrollment directory in China since 2012, and has developed rapidly in recent years. In 2018, the Ministry of Education of China promulgated the National Standard for Undergraduate Teaching Quality of Foreign Language and Literature Majors in Colleges and Universities and the Teaching Guide for Business English Majors (hereinafter referred to as The Guide) was issued in 2019, which makes detailed and clear provisions on business English teaching objectives, teaching specifications, curriculum system, teaching plan, teaching requirements, teaching evaluation, teaching staff, quality management and so on. The Guide emphasizes that interdisciplinary, practical and compound characteristics are the major features of business English teaching. It is of great significance to build the systematic practical teaching system so as to cultivate students' comprehensive innovation ability and individual all-round development.

Under the background of "new liberal arts" in China, 
this research discusses the reform and practice of practical teaching system, with a case study on the construction of provincial-level first-class Business English major in Yangtze University.

\section{RELATIVE STUDIES ON PRACTICAL} TEACHING SYSTEM

In recent years, some practical teaching research takes the institutions and universities as examples, or takes a discipline or curriculum design as the research objects, and some carry out case studies on practical course implementation, focusing on modeling analysis and demonstration. Most of the research is experimental training research in science and engineering departments or higher vocational colleges with fruitful results and new perspectives. But the practical teaching of humanities and social sciences is rarely involved, and there is little about the reform and development of practical teaching focusing on Arts \& Humanities.

In China, the research related to "practical teaching system" mainly focuses on the following fields: 1) Comparative research on practical teaching in colleges and universities: at the beginning of this century, the research mostly focused on introducing the practical training mode of foreign excellent science and engineering colleges. Huang Jiying (2006) introduced the professional practice of automobile industry in Aachen University in Germany and MIT in the United States, and made a comparison with Tsinghua University; 2) Hierarchical and classification research: it mainly studies the practical teaching system of different school levels, types and disciplines. 3) Research on system structure: it is mainly committed to building a differentiated practical teaching system structure, such as "Three Levels and Three Platforms" practical system (Yuan Xun, 2011).

Business English major has developed rapidly since 2010s. Most of the relevant studies focus on discipline orientation, interpretation of the national Teaching Guide for Business English Majors, curriculum model reform and evaluation system (Wang Lifei, 2013;2016). However, at present, the research on business English practical teaching system is not sufficient, especially lack of systematic indepth study of operability under the background of "new liberal arts".

\section{RESEARCH OBJECT}

This research investigates the existing problems of the practical teaching system, and systematically discusses the design principles of the practical system, the construction of the practical system model, the optimization of the practical system, the guarantee measures of the practical teaching system and the evaluation of the practical teaching system, aiming to explore the new path of the practical system of the first-class major of Business English.

\section{RESEARCH DESIGN}

1) Firstly, through extensive literature study, this research sorts out the present situations and existing problems of Business English practical teaching in China and clarifies the connotation, design principles, construction objectives, main structure and main contents of Business English practical teaching system under the background of new liberal arts.

2) Secondly, combined with the investigation of the current situation of discipline construction and the employment market, this research tries to build a new approach for the construction of Business English practice system with distinctive characteristics of "experiential learning and practical empowerment". The design principles are clarified and a practical teaching model is proposed.

3) Then, a case study was carried in the experimental class. The implications and suggestions will be summarized to realize further optimization and improvement of practical teaching system. 


\section{THE PRESENT SITUATIONS AND EXISTING PROBLEMS OF BUSINESS ENGLISH PRACTICAL TEACHING IN CHINA}

\subsection{Introduction to Business English teaching}

Business English, as a variant of ESP used in business activities, involves all fields of business communication such as economy, trade and law. At present, business English is booming in many countries all over the world and many colleges and universities have set up business English courses. Specifically, the purpose of business English course should be to cultivate senior application-oriented and management talents who are familiar with all aspects of business course and armed with strong social skills, and can use English to carry out business activities and solve business disputes. Since the 1990s, China's market economic system has been established and gradually improved, the process of economic globalization has accelerated, and the talents who can use English to directly engage in international business activities are extremely short of. Therefore, it promotes the rapid development of business English teaching in China. In 2007, Business English was established as a new major (major code 050258) with the approval of the Ministry of Education. Business English has become an emerging major with good employment and high social recognition. Some domestic colleges and universities began to recruit master's students in Business English, and since 2012, the doctoral program of Business English has started enrollment. An overall and systematic talent training system and model and has been established and has been greatly valued by society.

Business English originated from ESP in Applied Linguistics. It has developed from theory to practice, forming an interdisciplinary and building an independent discipline system. With the development of business English, the subject orientation has been gradually clear. It is a new subject produced by the intersection of Applied Linguistics and international business, international trade, world economy and other disciplines. However, the objectives and emphasis of talent training are different. It is a new mode and way of special foreign language talent cultivation. Business English mainly cultivates international compound foreign language talents who are proficient in foreign languages and business. They are engaged in information research, business speech and negotiation, business law, business writing and translation in the fields of transnational investment, transnational litigation, transnational trade and transnational management. They are required to have comprehensive language application ability and communication ability, be familiar with relevant business professional knowledge, and be familiar with foreign culture and international situations. Compared with foreign language teaching, it emphasizes cross-cultural communicative competence and business practice ability. The significance of practical teaching in Business English teaching is becoming more and more prominent

\subsection{Introduction to practical teaching of Business English}

Practice is an objective activity for human beings to understand and transform the world purposefully in a certain social organization. Practical teaching refers to all practical activities that run through the whole teaching process and are actively participated by teaching subjects in order to inherit knowledge, develop ability, explore and innovate and improve professional quality. The main contents include: classroom practices, case studies, the extracurricular activities, practical operation inside and outside campus, vocational training, simulation, innovation and entrepreneurship training, graduation design, etc., which processes systematic, comprehensive, flexible and interdisciplinary characteristics.

The teaching objective is to cultivate high-quality talents with international vision, cross-cultural ability, innovative spirit and comprehensive professional quality. Practical teaching requires students to have a strong sense of social responsibility and innovation, be able to skillfully apply various business professional skills and knowledge in business work, reasonably analyze various business 
activities, solve various business problems, and fulfill their responsibilities, so as to achieve the purpose of combining theory with practice in teaching.

\subsection{Existing problems in Business English practical teaching}

This research takes the methods of literature review, investigation, questionnaire survey and interview to comprehensively investigate the current situation and sort out existing problems of the construction practice teaching system of business English majors. The research group has investigated more than 10 domestic colleges and universities and has visited many enterprises in China to deeply understand the call of enterprises in the market. Then, combined with the interview and questionnaire of Business English majors in Yangtze University, this paper investigates the teachers' understanding and students' expectations. Based on the investigation, this research found there are still some deficiencies and problems existing in the present Business English practical teaching.

1) Lack of school standards and clear training objectives of practical teaching. The school standards that truly implement the Guide have not been formulated. The objective of practical teaching is still not clear, resulting in insufficient attention to practical teaching and operation.

2) Lack of system design of practical teaching. First, the practical teaching system is incomplete, the organization of practical teaching links is lack of continuity, systematisms, mutual coordination and cohesion. Second, there is a lack of special practical teaching planning, management, research and evaluation mechanism. Third, there is a lack of effective internal connection among curriculum sections, thus the subjects of the curriculum cannot form a coherent one.

3) The practical teaching methods and curriculum system are relatively backward. First, the general training does not match the personalized needs of enterprises, and is out of touch with the development of the industry. Second, there is a lack of connections between theoretical courses and practice course. The practical teaching still depends on theoretical teaching, or there is a lack of authentic practice in practical teaching. Third, the content of practical teaching is out-of-date, and the teaching methods and means are relatively backward. Forth, the practice teaching is lack of effective guidance and evaluation, and the systematic construction has not been realized.

4) There is still a lack of high-quality ESP teachers with professional business background who can adapt to the change of the times and economic development.

5) The mutual cooperation mechanism between schools and enterprises is not smooth. The off-campus practice base is unstable and the resources are limited; few enterprises or industry experts participate in the formulation of curriculum plan and practical syllabus.

6) The assessment and evaluation system of practical teaching is unscientific and imperfect. There is a lack of independent evaluation standards that keep pace with the times and concerns about students' all-round development. Summative assessment is over emphasized, while formative evaluation is ignored.

\subsection{The construction of Business English practical teaching system}

\subsubsection{System design principles}

The design of practical teaching system must meet the requirements of talent training objectives and the social requirements for professional business talents. The new liberal arts characteristics of Business English are mainly reflected in interdisciplinary integration and collaborative training of government, colleges, markets and research institutions which emphasizing the qualities of innovation and integration, coordination and sharing.

The construction of practical teaching system should follow the following principles: (1) Set dynamic training principles to meet the needs of society. The training objectives should be dynamically adjusted with social progress and market requirements to ensure that the talent training mode can adapt to the changing social needs. (2) Focus on cultivating professional application ability, innovation and cross-cultural communication ability. The 
relationship among knowledge, ability and quality need to be clarified, while the cultivation of application ability and innovation ability need to be highlighted. (3) Realize optimization of curriculum system. Practical teaching system is a complete organic system, including the overall structure of the system, the type and content of practical courses, etc. All elements should be taken into account to achieve the overall optimal effect, so as to ensure the efficient and high-quality operation of the practical teaching system and facilitate the cultivation of inter-disciplinary talents.

\subsubsection{Main contents of the practical teaching system}

Based on the core implementation idea of "knowledge accumulation and improvement + ability training and enhancement + critical thinking cultivation", this research put forward the reconstruction of the practical training system of Business English, mainly focusing on basic knowledge, humanism and societal responsibility, practical skills, entrepreneurship and innovation.

The main contents of the system include: capstone design of school curriculum standard and talent training plan, in-course and out-of-course integration of practical teaching, training platform construction in school, practice base construction out of school, teaching staff development, innovation and entrepreneurship training, and practical teaching evaluation system, etc. The main implement forms include: four-level practical teaching of business English "Experience Teaching" (I, II, III, IV), in-school training based on virtual simulation experiment platform, out-ofschool practical practice based on enterprises and government support, college students' innovation and entrepreneurship training program, vocational qualification certification program, academic competitions and programming contest, reform on graduation design, etc.

\subsubsection{A case study}

This research takes a case study on the experimental class majoring in Business English in Yangtze University to explore an effective approach to realize systematical practical teaching. The experimental class is formed from
2020 with 30 undergraduate students.

The curriculum design broke the separation between theory and practice courses, so as to realize the organic integration of a modular curriculum system with targeted training projects. First, we constructed a special professional core knowledge system of "Courses on Language + Courses on Business + Courses on Overall Qualities Development". The curriculum are classified into five main modules, including English language knowledge, vocational knowledge (business + management), cross-cultural communication, innovation and entrepreneurship and humanistic qualities. The practical teaching content system runs through these five knowledge modules horizontally, including three skill modules of "basic skills" (such as language skills), "professional skills" (such as business negotiation skills, foreign business law and other vocational skills), and "comprehensive innovation ability training" (such as cross-cultural communication and entrepreneurship), which are integrated into the teaching plan of each academic year (I, II, III, IV) in a step-up manner. Among the above five knowledge modules and three skill modules, practical teaching is completed step by step from easy to difficult, from single to comprehensive, and from perception to application

(1) Task oriented in-class learning is the foundation of knowledge accumulation and improvement. It is proved that task-based learning promotes students' mastery of knowledge. (2) Professional practice driven by project is widely adopted all through the teaching process which is beneficial to students' ability training and development. (3) Critical thinking and team spirit is encouraged. (4) Internalization of knowledge and practice is emphasized during the enhancement of practical training. (5) The finial purpose of practical teaching is to realize the cultivation of "whole person" with innovative ideas, entrepreneurship spirit and humanistic qualities.

The main teaching design is as follows: Business English Experiential Learning (I, II, III) courses are offered in the lower grades and three summer vacations respectively, 
and Business English Research Experiential Learning (IV) courses are offered in the graduation semester. Among them, the social practice in school practical teaching base and in enterprises will be carried out on the holidays after the end of the third, fourth and fifth semesters respectively. Students are required to enter enterprises for three consecutive holidays (online and offline alternative) with no less than three weeks of personal practice. The dual-tutor system is adopted, and the professional tutors in the school and the enterprise tutors in the cooperative enterprise practice base outside the school provide practical guidance and feedback to the students

For example, in the first period of Experiential Learning, students will learn the practical operation of international trade with real account. And the following practice and knowledge is supposed to be mastered through practical training: (1) procedures and practices of foreign trade business; (2) basic skills of transaction negotiation; (3) business planning, using the network to publish advertisements and search information; (4) building partnerships with business partners; (5) import and export accounting; (6) the process of transaction negotiation and the signing of export contracts; (7) transportation, insurance and claims of import and export goods, (8) import and export inspection and declaration, preparation of documents, negotiation and settlement of foreign exchange, and handling export verification and tax refund.

These practices are the necessary skills for business English majors which cannot acquired merely in classroom teaching. Students are required to practice these with real enterprise account in groups, with the instruction from both teachers and enterprise mentors. The evaluation pays attention to process assessment and comprehensive ability evaluation, and was implemented in each stage of dynamic modular and hierarchical practical teaching. The investigation and effect tracking assessment on enterprises and employers was carried out.

After two-year experimental study, we found that the experimental class students own much higher professional satisfaction and higher enterprise recognition. In this class, 40 percent students has passed English Test for International Communication (ETIC), 30 percent students got Business English Certificate (BEC), 96 percent students has passed the Test for English Majors(TEM) Band 4, while 7 groups has participated the Innovation and Entrepreneurship Training Program for College Students with great achievement. The cross cultural communication ability, innovation and entrepreneurship ability, critical thinking, teamwork spirit, leadership, multidisciplinary comprehensive application ability and comprehensive professional quality have been effectively improved.

\section{FURTHER DISCUSSIONS}

The "Experiential Learning" practical teaching system based on the "new liberal arts", highlights the application characteristics of Business English major, and carries out modular, hierarchical and diversified experiential teaching approach. The feedback from enterprise evaluation generally shows that our students have broad vision, excellent ideological, strong team spirit and problemsolving ability. Students' employment concept has changed, they have courage to break through and are willing to bear hardships.

Due to limited time and practice training resources, there are still some limitations that need to be improved in the further study. First, following the principle of dynamic training to meet the needs of society, we need to continue to optimize the content and structure of experiential learning, and then realize the professionalization of training environment and the rationalization of curriculum structure. Second, school and enterprise cooperation need to be strengthened and thus realize industry customization and personalized training. It is necessary to encourage enterprise tutors and school teachers to jointly formulate practical teaching syllabus and teaching plan, and explore practical teaching mode in line with the development of the times and local economic development. Third, the diversified evaluation mechanism based on output and sustainable 
development should be established, including not only the achievement evaluation of various learning effects with professional competence, but also the evaluation mechanism of external enterprises to realize dynamic evaluation and monitoring.

\section{FUNDING}

This work was supported by the Hubei Provincial Department of Education, P.R.China [Grant No.:18Y056]; the Academic Affairs Office of Yangtze University [Grant No.: 2021]; and the Institute of Science and Technology Development, Yangtze University, P.R.China [Grant No.:2018csz07];

\section{REFERENCES}

[1] Jones L, Alexander R. International Business English Student's Book. Cambridge University Press. 1994

[2] Wang Lifei. Analysis on the Current Situation of Business English Research in China in the Past Ten Years ( $2002-$ 2011). Foreign Language World. 2013(04)

[3] Huang Jiying. International Case Studies of Practical Education. Tsinghua Journal of Education. 2006 (04)

[4] Yuan Xun. Exploration and Practice on the Cultivation of Applied Talents and the Construction of Practical Teaching System in Local Colleges and Universities. Experimental Technology and Management. 2011(08) 